\title{
Virallisen tarkastajan lausunto
}

Kasvatustieteiden osaston määräämänä lis. Juha Varilan väitöskirjaksi tarkoitetun tutkimuksen "Koetusta koulutustarpeesta ja sitä selittävistä tekijöistä" virallisena vastaväittäjänä esitän tutkimuksesta lausuntonani kunnioittaen seuraavaa:

Lis. Varilan tutkimus kohdistuu ongelma-alueeseen, joka aikuiskoulutuksen nykyisessä ekspansiovaiheessa ja opetusteoreettisten perspektiivien syvetessä kohti yhä tulkinnallisempaa koulutusnäkemystä on hyvin ajankohtainen. Koulutustarpeen arviointeja on suoritettu suomalaisessa aikuiskoulutuksessa runsaasti jo viime vuosikymmenellä ja sitä on käsitelty "teoreettisesti" monissa artikkeleissa. Sen olemuksen ja käsitteellisen rakenteen analysointi on kuitenkin jäänyt vähemmälle. Huomio on kiinnitetty mieluim- min tarpeen määrittelyn lähtökohtiin. On saatu aikaan metodisia ratkaisuja, joita sitten on ryhmitelty analyysitason tai tarpeen määrittäjän mukaan. Vasta uudempi sosiologinen, opetusteoreettinen ja työpsykologinen tarkastelutapa on johdattanut tutkijat syvällisempään koulutustarpeen käsiteanalyysiin.

Varila on tutkimuksessaan myös pyrkinyt syvällisempään koko koulutustarpeen ja varsinkin koetun koulutustarpeen käsitteen analyysiin. Hän on laajasti perehtynyt alan teoreettiseen kirjallisuuteen samoin kuin viimeaikaisiin tutkimusraportteihin. Koulutustarpeen kompleksisuudesta johtunee, ettei sen järjestelmällinen synteesiin tähtäävä käsittely ole tässäkään tutkimuksessa onnistunut. Vaikka tekijä ansiokkaasti osoittaakin alan kirjallisuuden tuntemuksensa, jää lopputulos referaa- tiksi, jossa luokitus toisensa jälkeen vyöryy lukijan eteen. Sen lisäksi tekijä ei suostu sitoutumaan mihinkään kuvailemistaan koulutustarpeen elementeistä, vaikka tutkimuksen paikantaminen empiirisen osan perusteella on täysin tehtävissä.

Koetun koulutustarpeen analyysi tiivistyy ja saa edellistä enemmän syvyyttä, vaikka tarpeen käsitteen analyysi jää kapeaksi ilman syvällisempää psykologista tarkastelua. Herääkin kysymys, onko koulutustarve sanan psykologisessa mielessä vai olisiko puhuttava koulutusodotuksista tai reaktiotaipumuksista hakeutua koulutukseen.

Tutkimuksen teoreettisessa analyysissä päädytään Scissonsin näkemykseen, ettei ole yhtä ainoaa oikeaa koultustarpeen määrittelytapaa. Tarveanalyysin tulos riip- 
puu siitä, mitä tarpeen määrittäjä painottaa tarvetta arvioidessaan ja miten hän tarpeen määrittää, mittauksin operationaalistaa. Tutkimuksen empiirisen osan lähtökohtana on Scissonsin koulutustarpeiden typologia. Vaikka tutkija onkin perehtynyt typologian perusteisiin perusteellisesti, olisi ollut syytä paneutua Scissonsin em. varoittaviin huomautuksiin syvällisemmin.

Tutkimuksen empiirinen osa jakaantuu kuvailevaan ja selittävään osaan. Kummankin osan pääongelmat ovat selkeitä ja tutkimuksen päätarkoituksen mukaisia. Kuvailevan osan alaongelmien suhteen voidaan tutkijan kanssa olla eri mieltä siitä, mikä tarvekomponenttien erilaisuutta tarkasteltaessa on relevanttia ja mielenkiintoista. Tutkija on valinnut erilaisuuden selvittämisen ydinkysymykseksi erojen sleivttämisen niden intensiteetissä. On ensinnä kysyttävä, voidaanko tarpeen voimakkuutta mitata kovin tarkalla mitta-asteikolla. Kykenemme verrattain karkeasti toteamaan, että tarpeet jollakin alueella ovat vahvemmat kuin toisella. Tutkija on kuitenkin käyttänyt 7-tasoista intensiteettiskaalaa, jossa tasojen vivahde-erot ovat hyvinkin tulkinnallisia ja itse asteikko toimii vain järjestysasteikon tasolla. Kunkin komponentin sisällön rakenne on pakotettu faktorianalyysin pääakselimentelmällä kaksiulotteiseksi, jotta intensiteettivertailu olisi helpompaa. Tämä menettely on täysin hyväksyttävä intensiteettierojen
Tehtäväosioiden arviointiasteikko olisi kuitenkin pitänyt laatia karkeampijakoiseksi ja sitä kautta yksiselitteisemmäksi.

Toinen kysymys onkin sitten, miksi ei tutkittu myös komponenttien rakenne-eroja käyttämällä tähän erilliseen tutkimusongelmaan faktorianalyysin pääkomponenttianalyysiä ja Varimax-rotaatiota tai vinorotaatiota. Näin kukin komponentti olisi saanut vapaasti avautua kutakin luonnehtiviin ulottuvuuksiin. Olisi nähty, jäsentyykö tehtäväavaruus eri tavoin, kun arvioidaan pätevyyttä, tärkeyttä ja opiskelumotivaatiota.

Selittävän osan pääongelmana oli tutkia, ovatko arvioitsijoiden näkemykset kasvatuksen ja kouluksen vaikuttavuudesta yhteydessä koetun koulutustarpeen intensiteettiin. Asetelma on toki mielenkiintoinen ts., onko koulutustarvearviointeja ohjaamassa arvioitsijoiden omaksuma kasvatus- ja koulutusasenteisto tai jopa jonkintasoinen filosofia. Hieman yllättävä oli tulos, että laaja-alaisempi ja ehkä epämääräisempi näkemys kasvatuksen vaikuttavuudesta selitti tarvearvionteja voimakkaammin kuin konkreettisempi näkemys koulutuksen vaikuttavuudesta. Yksi selitys voi löytyä mittareista. Niiden osioita analysoimalla jää vääjäämättä vaikutelma, että mittareiden nimet ovat vaihtuneet. Riippuvuudet selittäjien ja selitettävien välillä jäävät kovin pieniksi. Vaikka monet indeksit poikkesivatkin merkitsevästi nollasta, jäi niiden selitysprosentti alhaiseksi. Regressiona- lyysien merkitsevyyksien tulkintaa vie harhaan tekstiin jäänyt valitettava systemaattinen painovirhe. Multippelikertoimien (R) sijasta selitysvoimaa kuvaa sen toinen potenssi eli selitysprosentti.

Tutkimusraportissa on muutamia muitakin sisältöön liittyviä huolimattomuuksia, kuten Scissonsin typologian kuvion puutteellisuus (s. 30). Pahimpana puutteena lukijan kannalta voidaan kuitenkin pitää eräiden oleellisten liitteiden puuttumista, kuten taustamuuttujien varianssianalyysit ja faktorianalyysien kommunaliteettien puuttuminen.

Tutkimuksen ansiot ovat ennen kaikkea sen teoreettisessa osassa ja erityisesti koetun koulutustarpeen analyysissä. Enemmän puutteita ja pinnallisuutta löytyy empiirisessä toteutuksessa. Tutkija perustelee kyllä teknisellä syvällisyydellä metodivalintansa, mutta aineiston istuttaminen hyvin valittuun menetelmäkehikkoon jää pinnalliseksi, eikä lopputulos vastaa tutkijankaan ennakkohypoteeseja. Työn teoreettiset ansiot ja metodien tekninen hallinta painavat kuitenkin enemmän kuin empiirisen toteutuksen puutteet. Lis Varila puolusti väitöstilaisuudessa tutkimustaan hyvin.

Esitän mielihyvin kasvatusteiteiden osastolle, että lis. Juha Varilan tutkimus hyväksyttäisiin kasvatustieteen tohtorin arvoon oikeuttavana opinnäytteenä.

Jorma Ekola 